\title{
REFINEMENT OF JENSEN'S INEQUALITY WITH APPLICATIONS TO CYCLIC MIXED SYMMETRIC MEANS AND CAUCHY MEANS
}

\author{
Ilko Brnetić, Khuram Ali Khan AND Josip PeČARIĆ
}

Abstract. Generalized refinement of Jensen's inequality is given. Appplications are done for cyclic mixed symmetric means and Cauchy means.

Mathematics subject classification (2010): Primary 26D07, 26D15, 26D20, 26 D99.

Keywords and phrases: Convex function, mixed symmetric means, exponentially convex function, Cauchy means.

\section{REFERENCES}

[1] M. ANWAR AND J. PEČARIĆ, On log-convexity for differences of mixed symmetric means, Mathematical Notes, Vol. 88, No. 6, 776-784, (2010).

[2] M. BenCZE And S. Wu, New inequalities obtained by rearrangement, Octogon Mathematical Magazine, Vol. 21, No. 2, 593-612, (2013).

[3] I. BRnetić, C. E. M. PEARCE And J. PeČArić, Refinements of Jensen's inequality, Tamkang Journal of Mathematics, Vol. 31, No. 1, (2000).

[4] L. Horváth, K. A. Khan and J. PeČArić, Refinements of Results about Weighted Mixed Symmetric Means and Related Cauchy Means, J. Inequal. Appl., Vol. 2011, Article ID 350973, 19 pages, (2011).

[5] L. Horváth, K. A. Khan And J. PeČArić, Further Refinement of Results about Mixed Symmetric Means and Cauchy Means, Advances in Inequalities and Applications, 1 (2012), No. 1, 12-32.

[6] J. JaKŠEtiC And J. PeČARIĆ, Exponential Convexity Method, Journal of Convex Analysis, 20, 1 (2013), 181-197.

[7] K. A. Khan, J. PeČArić And I. Perić, Differences of weighted mixed symmetric means and related results, Journal of Inequalities and Applications, Volume 2010, Article ID 289730, 16 pages, (2010).

[8] J. PeČARIĆ AND J. Perić, Improvement of the Giaccardi and the Petrović Inequality and Related Stolarsky Type Means, An. Univ. Craiova Ser. Mat. Inform. 39, 1 (2012), 65-75.

[9] J. Pečarić, F. Proschan and Y. L. Tong, Convex functions, Partial Orderings and Statistical Applications, Academic Press, New York, (1992).

[10] J. L. SCHIFF, The Laplace transform. Theory and applications, Undergraduate Texts in Mathematics, Springer-Verlag, New York, (1999). 